\title{
Hepatitis B Virus Adaptation to the CD8+ T Cell Response: Consequences for Host and Pathogen
}

\author{
Sheila F. Lumley ${ }^{1,2}$, Anna L. McNaughton ${ }^{1}$, Paul Klenerman ${ }^{1,2,3}$, Katrina A. Lythgoe ${ }^{4}$ \\ and Philippa C. Matthews ${ }^{1,2,3 *}$
}

${ }^{1}$ Medawar Building for Pathogen Research, Nuffield Department of Medicine, University of Oxford, Oxford, United Kingdom, ${ }^{2}$ Department of Infectious Diseases and Microbiology, Oxford University Hospitals NHS Foundation Trust, John Radcliffe Hospital, Oxford, United Kingdom, ${ }^{3}$ Oxford BRC, John Radcliffe Hospital, Oxford, United Kingdom, ${ }^{4}$ Nuffield Department of Medicine, Big Data Institute, University of Oxford, Oxford, United Kingdom

\section{OPEN ACCESS}

Edited by:

Gkikas Magiorkinis, National and Kapodistrian University

of Athens, Greece

Reviewed by:

Antonio Bertoletti, Duke-NUS Medical School,

Singapore

Joerg Timm,

Heinrich-Heine Universität

Düsseldorf, Germany

Robert Thimme,

Albert Ludwigs Universität

Freiburg, Germany

*Correspondence:

Philippa C. Matthews

philippa.matthews@ndm.ox.ac.uk

Specialty section:

This article was submitted

to Viral Immunology,

a section of the journal

Frontiers in Immunology

Received: 12 April 2018

Accepted: 25 June 2018

Published: 16 July 2018

Citation:

Lumley SF, McNaughton AL, Klenerman P, Lythgoe KA and Matthews PC (2018) Hepatitis

$B$ Virus Adaptation to the

CD8+ T Cell Response:

Consequences for Host

and Pathogen.

Front. Immunol. 9:1561.

doi: 10.3389/fimmu.2018.01561
Chronic viral hepatitis infections are a major public health concern, with an estimated 290 million individuals infected with hepatitis B virus (HBV) globally. This virus has been a passenger in human populations for $>30,000$ years, and remains highly prevalent in some settings. In order for this endemic pathogen to persist, viral adaptation to host immune responses is pre-requisite. Here, we focus on the interplay between HBV infection and the CD8+ $T$ cell response. We present the evidence that CD8+ $T$ cells play an important role in control of chronic HBV infection and that the selective pressure imposed on HBV through evasion of these immune responses can potentially influence viral diversity, chronicity, and the outcome of infection, and highlight where there are gaps in current knowledge. Understanding the nature and mechanisms of HBV evolution and persistence could shed light on differential disease outcomes, including cirrhosis and hepatocellular carcinoma, and help reach the goal of global HBV elimination by guiding the design of new strategies, including vaccines and therapeutics.

Keywords: hepatitis B virus, evolution, adaptation, diversity, CD8+ T cells, adaptive immunity, human leukocyte antigen

\section{INTRODUCTION}

Within hosts, viruses with high mutation rates can rapidly adapt to the selection pressures placed upon them, including natural and vaccine induced immune responses, and antiviral therapy. Hepatitis B virus (HBV) represents a substantial international public health challenge, with an estimated 290 million people chronically infected globally (1). In this review, we explore the evidence for $\mathrm{HBV}$ escape from the $\mathrm{CD} 8+\mathrm{T}$ cell response and examine the influence this process could have on infection outcomes.

\footnotetext{
Abbreviations: C HBV, core gene; CARs, chimeric antigen receptors; cccDNA, covalently closed circular DNA; GWAS, genome wide association studies; $\mathrm{HBV}$, hepatitis $\mathrm{B}$ virus; $\mathrm{HBcAg}$, hepatitis $\mathrm{B}$ core antigen; $\mathrm{HBeAg}$, hepatitis $\mathrm{B}$ e antigen; HBsAg, hepatitis B surface antigen; HCC, hepatocellular carcinoma; HLA, human leukocyte antigen; KIR, killer-cell immunoglobulin-like receptors; NLG, N-linked glycosylation; ORF, open reading frame; P HBV, polymerase gene; PBL, peripheral blood lymphocyte; RT, reverse transcriptase; S HBV, surface gene; SNP, single-nucleotide polymorphism; TCR, T cell receptor; MHC, major histocompatibility complex; HIV, Human immunodeficiency virus; HCV, Hepatitis C virus.
} 
Hepatitis B virus belongs to the Hepadnaviridae family of small, enveloped, primarily hepatotropic viruses. At only 3,200 bp, HBV has one of the smallest genomes of all known pathogenic viruses. The partially double-stranded DNA (dsDNA) circular genome consists of four genes, $\mathrm{X}$, Polymerase $(\mathrm{P})$, Core $(\mathrm{C})$, and Surface $(\mathrm{S})$, and a high proportion of the genome is encoded on overlapping open reading frames (Figure 1). During transcription, the partially dsDNA genome is "completed" to form a fully dsDNA molecule, which is subsequently supercoiled to form covalently closed circular DNA (cccDNA). This cccDNA is reverse transcribed by $\mathrm{HBV}$ reverse transcriptase (RT), an enzyme lacking $3^{\prime}-5^{\prime}$ exonuclease proof-reading capacity, and therefore introducing mutations into the HBV genome during each round of replication [in duck hepadnavirus, the mutation rate is estimated at between $0.8 \times 10^{-5}$ and $4.5 \times 10^{-5}$ substitutions per nucleotide per replication (2)]. The mutations generated result in a viral quasispecies, comprised of dominant genotype(s) surrounded by clouds of closely related HBV variants.

The error prone RT, coupled with high rates of HBV replication [estimated at between 200 and 1,000 virions/hepatocyte/ day at the peak of infection (3)] results in the production of a large number of virions harboring mutations. The vast majority of mutations are likely to be deleterious, some are neutral, and a minority provide the virus with a potential selective advantage, such as escape from CD8+ $\mathrm{T}$ cell-mediated responses. However, HBV polymorphisms are constrained by the overlapping reading frame structure of the genome, since the majority of mutations can simultaneously affect multiple genes [these have been described as "mirror" mutations (4), Figure 2]. Mutations that are neutral or beneficial for one protein might be detrimental for another. Accordingly, overlapping regions of the HBV genome generally have less diversity compared to nonoverlapping regions (5) and the within-host rate of evolution at overlapping regions is about half that of non-overlapping regions (6).

Current vaccination and treatment approaches are hindered by poor diagnosis and access to treatment, drug and vaccine escape mutants, viral rebound on treatment cessation or immunosuppression, and lack of curative therapy (8). To make a significant impact on HBV prevalence, parallel improvements in diagnostics, treatment, and prevention are required; ultimately, new immunotherapeutic strategies may be key to the success of elimination. Developing a more robust picture of the extent, nature, and significance of the interplay between the virus and the host CD8+ T cell response is an important avenue of enquiry, enabling us to predict and tailor therapeutic interventions that may be beneficial in mediating control or clearance of chronic infection.

A robust body of data has been assimilated over the past few decades for HIV and HCV, informing significant understanding of the nature and impact of CD8+ $\mathrm{T}$ cell-mediated immune control and escape (Table 1). For HBV, there is a relative paucity of such evidence but the field could be advanced by similar approaches. We have therefore set out to assimilate the evidence

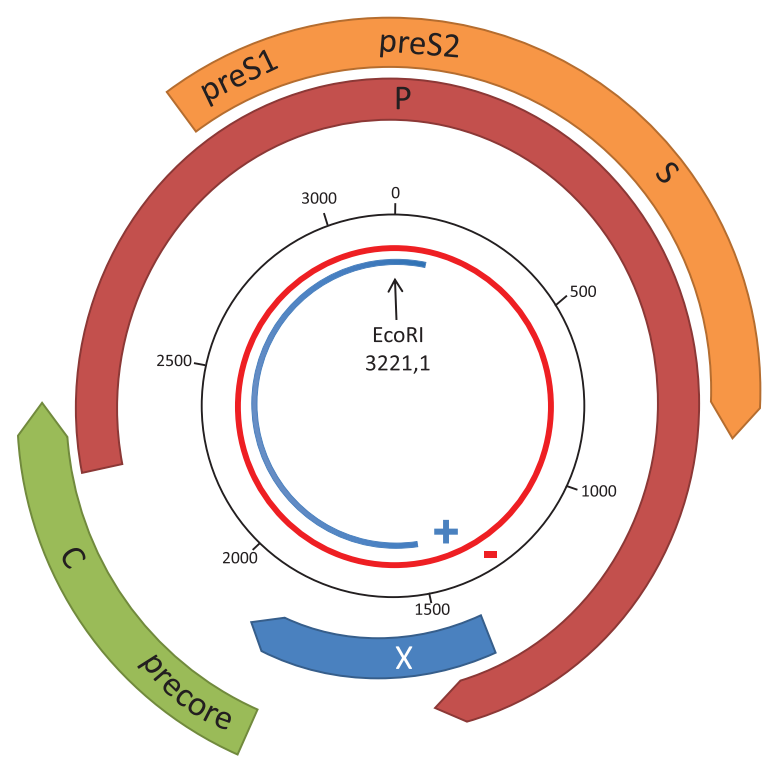

Gene $\mathbf{S} \rightarrow$ HBs protein

Outer envelope protein

Non-infectious subviral HBsAg particles outnumber infectious virions by $\times 100-10000$

HBsAg promotes T cell exhaustion.

Immune/diagnostic escape mutants

Gene $\mathbf{P} \rightarrow$ Polymerase

4 domains, with 3 enzymatic activities:

Terminal Protein (TP) domain: protein-priming function

Non-conserved spacer domain (no enzymatic activity)

Reverse Transcriptase domain: RNA-dependent DNA

polymerase (RT) and DNA-dependent DNA polymerase

RNase $\mathrm{H}$ domain: ribonuclease $\mathrm{H}$ activity

Drug resistance mutations
Gene $\mathrm{C} \rightarrow \mathrm{HBc} / \mathrm{HBe}$ proteins
$\mathrm{HBC}$ antigen: icosahedral nucleocapsid
$\mathrm{HBe}$ antigen: immunoregulatory roles
- viral persistence, suppresses anti-viral T cell responses against $\mathrm{HBcAg}$ by stimulating T-reg cells
- drive pro-inflammatory $T$ cell polarization during viral clearance
may induce immunologic tolerance in utero
Pre-core mutants truncates precore/core protein
Core promoter mutants - associated with fulminant hepatitis

Gene $X \rightarrow$ HBx protein

$\mathrm{HBx}$ regulates viral replication and host functions eg.

transcription, cell cycle progression, DNA damage repair, apoptosis

Truncation mutants associated with oncogenesis

FIGURE 1 | The overlapping genome structure of hepatitis B virus (HBV). The partially double-stranded circular DNA genome is shown with the negative strand in red and the positive strand in blue. The black numbered circle indicates the nucleotide position. The four genes, X, Polymerase (P), Core (C), and Surface (S) are represented by the thick colored arrows, with the main functional roles of the four genes shown in the boxes, and key impact of mutations shown in italics. 


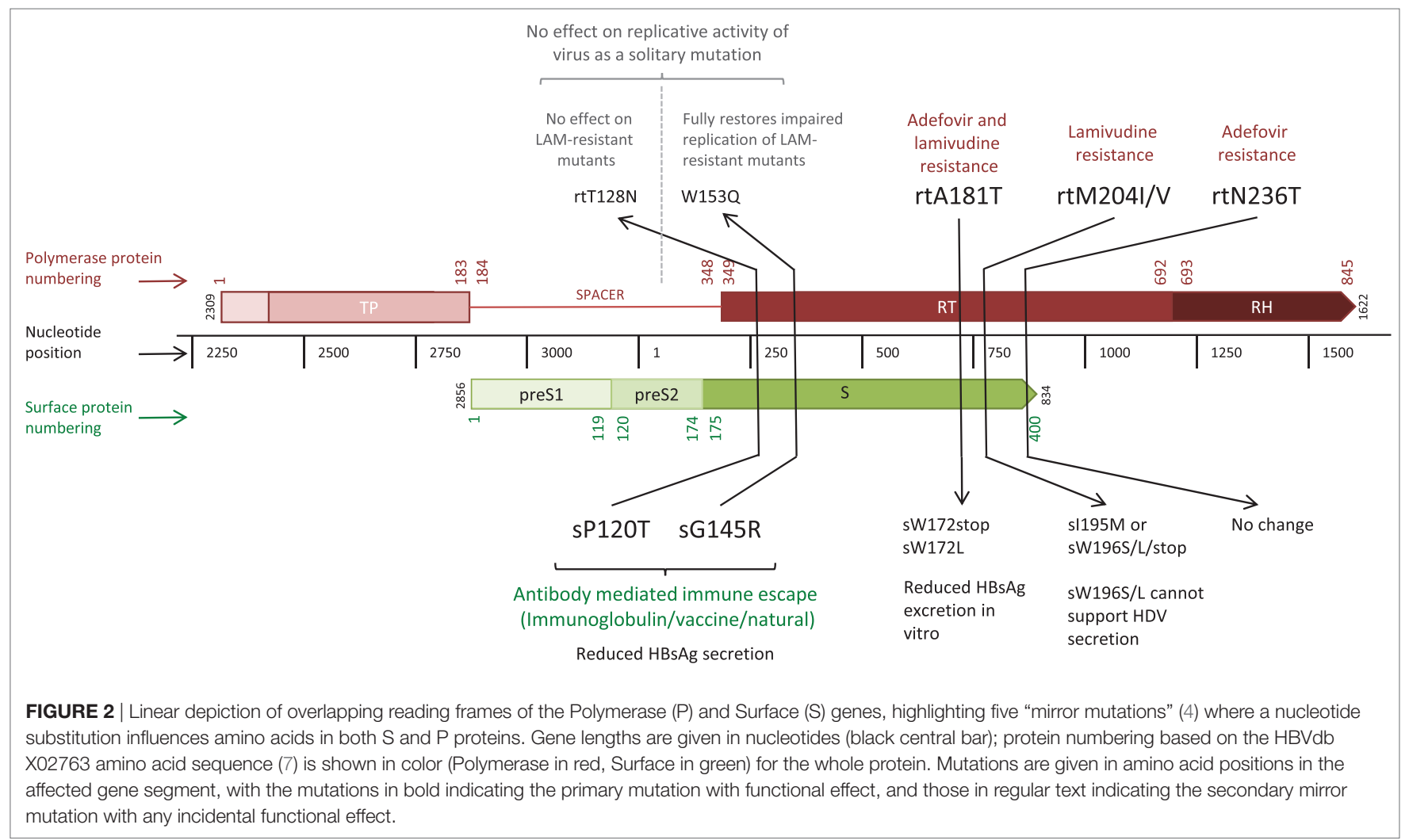

for viral adaptation to the host CD8+ T cell response in HBV infection, and to consider the significance of this adaptation both to viral fitness and function, and to host outcomes. Finally, we highlight gaps in our current understanding and knowledge, in order to provide foundations for ongoing research efforts.

\section{THE IMMUNOLOGICAL BASIS FOR ESCAPE}

Acute and chronic HBV infections are associated with functionally different CD8+ T cell responses (Table 1). Acute, selfresolving infections are characterized by functionally efficient, multi-specific antiviral CD8+ $\mathrm{T}$ cell responses which are sustained after viral clearance (9). Both non-cytolytic and cytolytic mechanisms have been implicated (22). In contrast, chronic infection is typically characterized by a lack of protective $\mathrm{T}$ cell memory maturation and exhausted HBV-specific CD8+ T cell responses (22-24).

Th1-polarized CD4+ $\mathrm{T}$ cells regulate and maintain CD8+ $\mathrm{T}$ cell responses and contribute to HBV clearance (80). Genome wide association studies (GWAS) have linked a range of human leukocyte antigen (HLA) class II alleles with disease outcomes. $\mathrm{CD} 4+$ responses are associated with vaccine responses (81) and clearance of acute infection $(82,83)$. Host HLA class II genotype has also been linked to treatment response (84) and to risk of developing hepatocellular carcinoma (HCC) (85). CD4+ $\mathrm{CD} 25+$ regulatory $\mathrm{T}$ cells suppress the activation, proliferation, and interferon- $\gamma$ production of both CD4+ and CD8+ T cells in chronic HBV infection $(86,87)$.
The highly polymorphic HLA class I genes are thought to be an important host factor for viral control, contributing to differences in HBV outcome observed globally. Host HLA polymorphisms and different $\mathrm{HBV}$ genotypes have been demonstrated to influence the rate of disease progression and the long-term outcome of HBV infection $(66,88,89)$. However, HBV can subvert various multiple steps of the CD8+ $\mathrm{T}$ cell antigen processing and presentation pathway to evade detection by the host (Figure 3, boxes 1-5). Thus, while all individuals with chronic $\mathrm{HBV}$ infection are at risk of increased progression to cirrhosis and HCC, individual outcomes depend on the interplay between host, viral, and environmental factors. In addition to HLA genes, other factors are implicated in disease outcome including age and duration of infection, other host genetic factors (90), and exposure to hepatotoxins (91).

\section{MECHANISMS OF HBV ESCAPE FROM CD8+ T CELL RESPONSES}

\section{Antigen-Processing Escape Mutants}

The amino acids flanking viral epitopes are important for effective antigen processing; mutations in these regions may impair proteasomal processing of the epitopes and are recognized in both $\mathrm{HCV}$ and $\mathrm{HIV}$ as a mechanism of CD8+ $\mathrm{T}$ cell escape $(100,101)$. Likewise, mutations altering the processing of HBV epitopes could be relevant for HBV escape from the CD8+ T cell-mediated immune response (Figure 3, box 1), however, none have been identified at present, potentially 
TABLE 1 | Strands of evidence for the significance of the CD8+ T cell response in control/clearance of infection with blood-borne viruses.

\section{Evidence for role of CD8+ $\mathrm{T}$ cell response in control of infection}

HBV (details and citations ${ }^{a}$ ) Functionally efficient, multi-specific antiviral CD8+ T cell responses (9)

HBV-specific CD8+ T cells reduce viral loads in HBV-infected HepG2 (hNTCP) cells (13)

Strong cytolytic response in woodchuck model (14)
HCV (details and citations ${ }^{a}$ )

HIV (details and citations ${ }^{\mathrm{a}}$ )
CD8+ T cell responses in acute infection associated with control and/or clearance

In vitro killing assays demonstrate efficacy/potency of CD8+ $\mathrm{T}$ cell response
CD8+ T cell responses are associated with clearance (10)

In vitro system using replicons demonstrates HCV-specific CD8+ T cells strongly inhibit viral replication through cytolytic and non-cytolytic mechanisms in a dose-dependent manner (15)

Rodent pegiviruses in vitro system shows promise (16)

Depletion of CD8+ T cell subsets impacts viremic control in vitro and in vivo

$\mathrm{CD}^{+}$depletion prolongs infection and delays viral clearance in chimpanzees (18)

\section{Viral infection is prolonged in} chimpanzees that previously cleared the infection after CD8+ T cells depletion (19) maturation and exhausted HBV-specific

\section{High PD-1 expression is associated} with chronic infection (30)
Disease progression is associated with $\mathrm{T}$ cell exhaustion in chronic infection

Lack of protective T cell memory CD8+ T cell responses are seen in chronic infection (22-25)

Blockade of inhibitory receptors PD-1 (26), CTLA-4 (27, 28), and Tim-3 (29) partly improve HBV-specific CD8+ T cell function in vitro

CD8+ $T$ cell responses may be required to maintain latency; viral mutations are associated with rebound or reactivation
Inverse relationship between magnitude of acute CD8+ T cell response in acute infection and subsequent viral setpoint $(11,12)$

CD8+ T cells targeting Gag show superior in vitro suppression of HIV replication (17)
Depletion of CD8+ T cell populations is associated with outgrowth of virus in vitro (20) and in the simian model in vivo (21)

PD-1 expression on HIV-specific T cells is associated with $T$ cell exhaustion and disease progression (31)
Modulation of cell surface HLA Variable surface expression of HLA is seen Variable surface expression of expression as a mechanism of immune evasion in human (37-39) and woodchuck hepatitis class I and class II $(41,42)$
Latency and reactivation are not typically associated with HCV infection
CD8+ T cell responses are associated with maintenance of latency, including during therapy, (35) and reviewed in Ref. (12)

Persistence of escape mutations in viral reservoir can lead to reactivation (36)

HIV Nef is associated with downregulation of cell surface HLA expression $(43,44)$ virus model (40)

Evidence of efficacy of $T$ cell vaccines

Heterologous prime-boost vaccines are promising $(45,46)$ Vaccine strategies assessed in woodchuck model (47)

HLA class I "footprints"specific HLA alleles associated with viral polymorphisms identified, CD8+ T cell epitope escape and reversion occurs genes (53-58)

Further data are required to develop appropriate animal models (59)
Evidence from animal models (48) and human vaccine constructs are in development (49)

\section{Viral footprints in HLA epitopes} display escape and reversion mutants identified (60-62)

\section{Footprints identified in all four HBV}

Vaccines expand the cellular immune response

in rhesus monkeys (50)

Reviewed in Ref. $(51,52)$
CD8+ $T$ cell escape mutations are associated with loss of viremic control; reversion to wild type is observed on transmission to an HLAmismatched recipient [literature reviewed in Ref. (63)] macaque model can influence disease outcome $(64,65)$

Particular HLA class I alleles associated with disease control

\section{HLA-A genotype is associated with} HBeAg status (66)

A database of HBV epitopes, "hepitopes," highlights instances in which outcome responses (53) is associated with specific $T$ cell

GWAS highlighting importance Associations identified but mechanisms of HLA class I genes in control of chronic infection
HLA-A*03 and HLA-B ${ }^{\star} 27$ alleles are protective in HCV infection $(61,67)$
Strong association with HLA-B genotype (68) e.g., control epitomized by CD8+ responses restricted by HLA-B*57 and HLA-B²7 (69-71)

aThe citations within this table aim to provide a robust overview of the evidence, using a combination of strong examples from the primary literature together with selected review articles that summarize specific aspects of this topic.

HBV, hepatitis B virus; HBeAg, hepatitis B e antigen; HLA, human leukocyte antigen; GWAS, Genome wide association studies; SNPs, single-nucleotide polymorphisms;

MHC, major histocompatibility complex; HCV, Hepatitis C virus; HIV, Human immunodeficiency virus. 


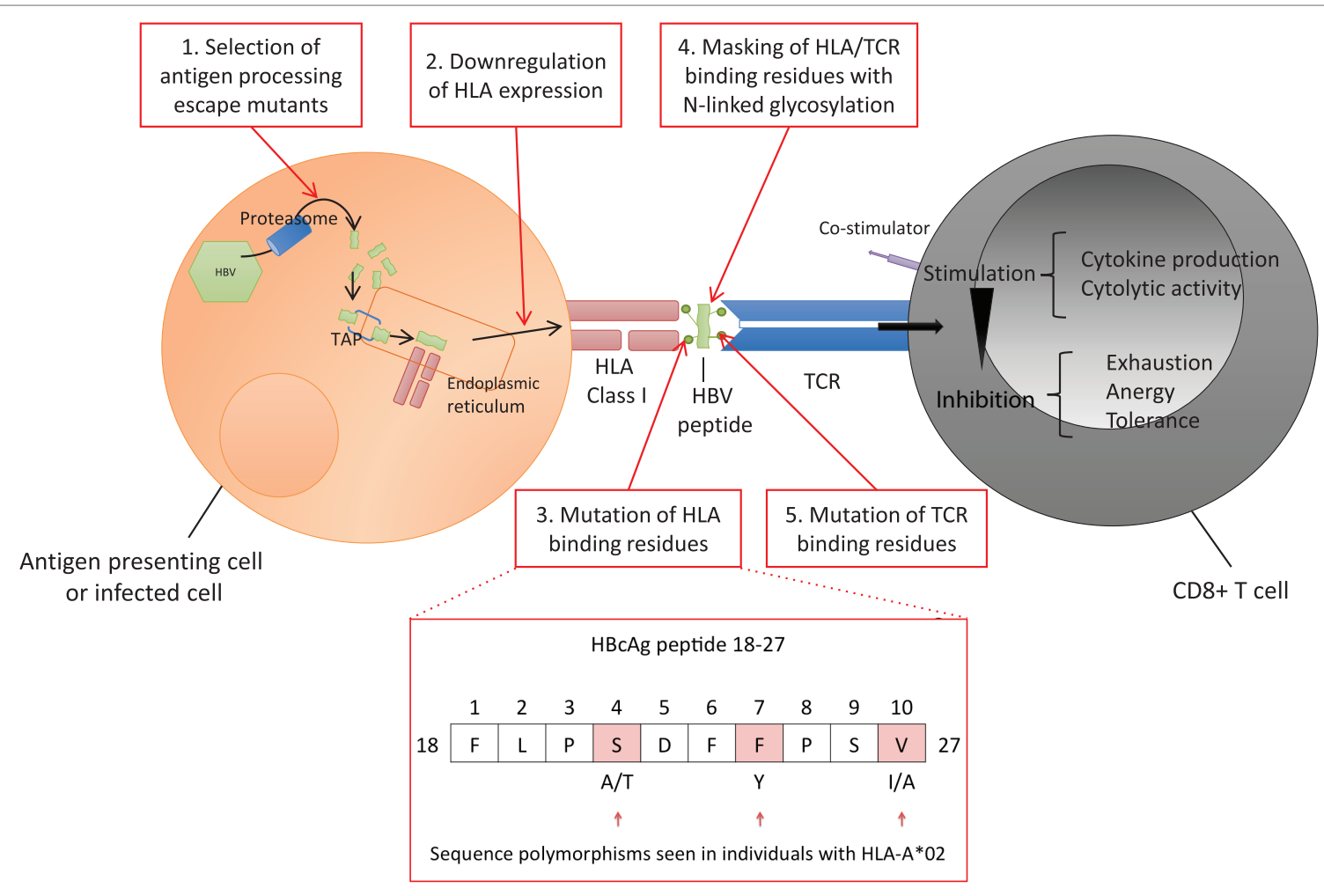

FIGURE 3 | Hepatitis B virus (HBV) evasion of the host CD8+ T cell-mediated immune response. Viral peptides are processed into 7-12 mers by proteasomal degradation and are transported via the Transporter associated with Antigen Processing (TAP) into the endoplasmic reticulum. Peptides containing an appropriate motif are bound by human leukocyte antigen (HLA) class I molecules and transported to the cell surface for expression (92). Each T cell receptor (TCR) binds a range of specific HLA-peptide combinations. TCRs are concentrated on the cell surface over time at an "immunological synapse" triggering intracellular signaling (93). HBV can potentially escape the host CD8+ response at a number of points. 1. Evading antigen processing, 2. Downregulating presentation (37-40), 3. Altering HLA binding residues (54-56, 94), 4. Masking HLA epitope with N-linked glycosylation (NLG) sites (32, 95), 5. Altering TCR binding residues of the epitope (10, 96-99). Examples of polymorphic sites in HBV core antigen HLA-A*02 restricted FV10 epitope (residues 18-27) are highlighted (54).

due to the focus on mutations lying within HLA-restricted epitopes rather than in the flanking regions.

\section{Virus Peptides Regulate Surface HLA Expression}

Virus-induced changes in HLA class I surface expression play an important role in viral pathogenesis and persistence (Figure 3, box 2). CD8+ $\mathrm{T}$ cells recognize $\mathrm{HBV}$-infected hepatocytes through presentation of HLA class I HBV epitopes on the cell surface (13), however, this expression can be upregulated or downregulated. Decreased presentation of class I MHC molecules on hepatocytes and lymphoid cells is described in the woodchuck hepatitis virus model (40). Changes in surface HLA have also been described in human HBV infection (37), for example, lower HLA class I has been associated with hepatitis B e antigen (HBeAg)-positive vs $\mathrm{HBeAg}$-negative status $(38,39)$. Interestingly, these studies are three decades old and have not been replicated in the more recent literature. Downregulation of HLA class II molecules by pre-core mutants has also been described during chronic HBV infection (102). Mutations altering the processing or presentation of HBV HLA class I epitopes, although not conclusively demonstrated, could hypothetically be relevant for escape from the CD8+ T cell-mediated immune response in human infection (Figure 3, box 2).

\section{Selective Mutation of HLA-Binding Residues}

Immune escape by selective mutation of HLA-binding residues within HBV CD8+ epitopes is one of the most commonly identified mechanisms for viral CD8+ immune escape (Table 1; Figure 3, box 3). Evidence of this escape mechanism in HBV has emerged through the identification of HLA class I "footprints" (94), mutations that are significantly enriched in patients with certain HLA class I alleles. Older literature was conflicting regarding the frequency and significance of such footprints in HBV (96, 103), but HLA footprints have subsequently been identified in all four HBV genes and mapped to known or predicted HLA epitopes [Table 1 (53)]. In some cases, these mutations result in altered peptide-HLA binding scores, providing a plausible mechanism for HBV immune escape, but have so far only been identified using cross-sectional data $(54,55,96)$. However, the pattern of escape is consistent across populations with divergent HLA haplotypes and different HBV genotypes, for example, genotypes $\mathrm{B}$ and $\mathrm{C}$ in a cohort of Chinese-origin 
patients (56), New Zealand-resident Tongans with chronic HBV genotype C3 infections (57) and Iranian patients with genotype D infection (58). Importantly, core mutants in patients with chronic genotype A or D infection have been confirmed to impair CD8+ T cell IFN- $\gamma$ secretion in vitro (54), indicating that these mutants could play an in vivo role in immune escape. These studies are limited by the sequencing methods (in which a predefined number of variants is typically selected for cloning and sequencing) reducing sensitivity for detection of low-abundance variant detection compared to newer ultra-deep sequencing methods.

Further studies have focused on identifying regions of the HBV genome with high within-host nucleotide diversity, and high rates of nonsynonymous substitutions, to determine which regions may be under strong HLA-mediated selection pressure. In a longitudinal study of eight HBeAg-negative asymptomatic HBV carriers, followed over 25 years, the ratio of synonymous to nonsynonymous mutations $(\mathrm{dS} / \mathrm{dN})$ in the core gene was low, suggesting high rates of positive selection, although no specific HLA-restricted epitopes were identified (104). Another study demonstrated low $\mathrm{dS} / \mathrm{dN}$ ratios in patients with sustained vs unsustained viral control following treatment, with specific surface antigen polymorphisms lying within HLA class I epitopes identified [sV14G, sF20S, sT45I, sI213L (105)], although this was not confirmed either with HLA genotyping or through demonstration of a functional impact on $\mathrm{T}$ cell recognition.

\section{Epitope Masking With N-Linked Glycosylation (NLG)}

$\mathrm{N}$-linked glycosylation is a post-translational modification that plays an established role in the antigenicity and infectivity of viruses $(106,107)$. NLG can mask immunogenic epitopes, interfering with antibody recognition of hepatitis B surface antigen (HBsAg), leading to immune and diagnostic escape $(32,95)$. It can also impact on HBV virion secretion, likely by altering the ability of envelope proteins to interact with the capsid surface (108-110). The number of NLG sites correlates with disease state, with increased NLG reported in patients with reactivated HBV vs chronic infection, and in those with sustained vs unsustained response off treatment $(32,111)$. Although the role of NLG in HBV evasion of CD8+-mediated T cell immunity is yet to be determined, it could potentially provide another strategy for immune escape by interfering with the binding of an HBV epitope to an HLA molecule, or the binding of an HLA-antigen complex to a cognate T cell receptor (TCR) (Figure 3, box 4).

\section{Alteration of TCR Recognition}

Engagement of the TCR with HLA class I/peptide complexes on antigen-presenting cells is key to activating CD8+ T cells; therefore, mutations in the TCR contact residues of an epitope can lead to immune escape. Immunodominance of viral epitopes is not simply determined by the amino acid sequence of the peptide and its binding affinity, but also depends on the peptide concentration and $\mathrm{T}$ cell clone, with the same HBV peptide able to induce different signaling cascades in different CD8+ T cell clones (97). Antagonist functions may provide HBV with a means of immune escape (Figure 3, box 5). Specifically, certain CD8+ T cell epitopes in hepatitis B core antigen (HBcAg) (97) and HBsAg (98) act as TCR antagonists, binding the TCR and inhibiting the $\mathrm{CD} 8+\mathrm{T}$ cell response. $\mathrm{HBeAg}$ may promote $\mathrm{HBV}$ chronicity by inducing CD8+ $\mathrm{T}$ cell tolerance. However, the underlying mechanisms driving this immune state in humans remain to be elucidated. Indeed, the mechanism may not involve presentation of an HLA class I-restricted epitope, as currently no epitopes have been identified that are unique to the pre-core sequence of $\mathrm{HBeAg}$ ( $\mathrm{a} 29$ amino acid stretch not shared with HBcAg) (112).

Chronic HBV infection is characterized by an exhausted CD8+ $\mathrm{T}$ cell phenotype associated with reduced cytotoxic activity and enhanced expression of inhibitory markers. TCR binding in the presence of high HBsAg levels induces $\mathrm{T}$ cell exhaustion, characterized by poor effector cytotoxic activity, impaired cytokine production and sustained expression of multiple inhibitory receptors. A hierarchy of co-inhibitory receptors, dominated by $\mathrm{PD}-1$, act synergistically to promote CD8+ tolerance. The degree of T cell impairment also depends on suppressive cytokines, interaction with other $\mathrm{T}$ cell subsets, and stage of T cell differentiation (113-117). T cell exhaustion is (at least partly) reversible; blockade of inhibitory receptors including PD-1 (26, 117), CTLA-4 (27), and Tim-3 (29) partly improve HBV-specific CD8+ T cell function in vitro. In addition, therapy with nucleot(s)ide analogs may lead to a modest reconstitution of HBV-specific T cell function (118). Although this restoration is transient (119), these CD8+ T cells can be associated with viral control upon therapy cessation (120).

\section{ESCAPE OVER SPACE AND TIME}

\section{Kinetics of Escape}

Evidence of immune-mediated selection has been found in HBV infection (53-56), although the kinetics of immune escape are yet to be robustly delineated. Longitudinal samples from the same individuals form the ideal dataset to address questions about the changes in viral sequence and diversity over time, but this has rarely been undertaken for HBV infection. One longitudinal study of HBV evolution following acquisition from a single source demonstrated an expansion and contraction of HBV diversity, with maximum diversity coinciding with peak viremia, and a predominance of nonsynonymous mutations with greatest diversity in the core gene (3). Further longitudinal data are required to unpick the timing and kinetics of viral evolution.

An area of HBV kinetics that has received some attention is the scenario of $\mathrm{HBeAg}$ loss. It is hypothesized that the change from $\mathrm{HBeAg}$-positive to $\mathrm{HBeAg-negative} \mathrm{occurs} \mathrm{by} \mathrm{one} \mathrm{of} \mathrm{two}$ mechanisms:

(i) Antibody-mediated control $(121,122)$ usually associated with low HBV DNA levels. This situation is most likely to be characterized by low viral sequence diversity, although the low viral loads make this difficult to study given the limits of sensitivity of next generation sequencing approaches. 
(ii) Selection of pre-core and promotor mutations (123), reducing or eliminating $\mathrm{HBeAg}$ production. In this case, $\mathrm{HBeAg-}$ negative status is associated with an increase in evolutionary rate and therefore with increased sequence diversity $(6,54$, 56, 57, 104, 111, 124-126). The cause/effect relationship between the increased evolutionary rate and the shift in immune activity is unclear. The higher viral mutation rate could lead to the occurrence of stochastic mutations, generating new $\mathrm{T}$ cell epitopes that disrupt immune tolerance, or could be the consequence of increased immune reactivity driving escape mutants.

\section{Compartment-Specific Evolution}

Compartment-specific evolution has been described for chronic viruses, including $\operatorname{HIV}(127,128)$ and $\operatorname{HCV}(129,130)$, although the evidence for $\mathrm{HBV}$ is very limited to date. The practical barriers to sampling tissue compartments longitudinally from the same patient make it difficult to assess the co-evolution of genetically distinct subpopulations over time [as is likely the case for HIV in the genital tract (131)].

Although hepadnaviruses are characteristically hepatotropic, HBV DNA is also found in a range of other tissues, including lymphatic cells. In the woodchuck model, life-long replicationand transmission-competent viruses persist in lymphocytes (132). However, it is difficult to demonstrate that hepatitis B virions isolated from different compartments in humans are replication and transmission competent, without a viable method of culturing autologous virus. There are some data to suggest that peripheral blood lymphocytes (PBLs) can support viral replication (133), but secretion of $\mathrm{HBeAg}$ and $\mathrm{HBsAg}$ from liver macrophages has not been detected [Lucifora, unpublished data, referred to in (134)].

HBV may undergo independent evolution in different tissue compartments, leading to compartmentalization of viral subpopulations (135-137); for example, HBV variants isolated from PBLs may be specifically adapted to this environment (137), potentially harboring relevant immune-escape mutants $(135,137)$. It has been hypothesized that compartment-specific mutants may serve as a source of reactivation or transmission and have been implicated in reinfection post liver transplant (138), mother to child transmission $(137,139)$, fulminant hepatic failure in the context of HIV co-infection (140), and antiviral escape (141).

Further work is required to confirm whether HBV does harbor replication and transmission competent viruses in cells other than hepatocytes. If this is confirmed, understanding host-virus dynamics at the compartmental level, studying the emergence of immune and antiviral escape mutants and the factors contributing to persistence and transmission will be crucial for developing improved therapeutics for HBV control.

\section{FUNCTIONAL IMPACT OF ESCAPE MUTATIONS ON HBV}

The primary functional impact of mutations within HLA class I-restricted $\mathrm{T}$ cell epitopes is to alter the frequency and/or functionality of the CD8+ T cell immune response. These mutations may have additional impact on the viral replication cycle and treatment response in the following ways:

(i) Altered structure/function of the viral protein containing the mutated immune epitope (Figure 2). This is seen in HBV escape from B cell immunity in which mutations within the $\mathrm{S}$ gene are associated with diagnostic failure (HBsAg mutants are not detected by the immunological assay) and treatment failure due to changes in assembly and secretion, virion formation and HBV infectivity $(109,142,143)$.

(ii) Effects of a "mirror" escape mutation on the overlapping gene (Figure 2). A mutation leading to amino acid substitutions in both the $\mathrm{P}$ and $\mathrm{S}$ genes, can simultaneously affect replicative capacity, drug resistance, and immunogenicity (142-145). Furthermore, deletions in regions such as the spacer region of Pol, neutral to Pol function, may lead to loss of immune epitopes in the overlapping preS1-preS2 region.

(iii) Impact of compensatory mutations mitigating for (i) and (ii). This is seen in replication deficient CD8+ immune escape mutants in HCV $(146)$ and HIV $(147,148)$ but has not yet been identified in HBV.

The full range of functional impacts of HBV CD8+ immune escape mutants has not been comprehensively explored. Understanding the functional impact of mirror and compensatory mutations that are associated with $\mathrm{CD} 8+\mathrm{T}$ cell-mediated selection may lead to further insights into the host-virus interaction.

\section{CLINICAL IMPACT OF VIRUS AND HOST POLYMORPHISMS ON HOST OUTCOME}

\section{Impact of HBV Mutations on Reactivation}

Hepatitis B virus reactivation as a consequence of immunosuppression has emerged as an important issue across a wide range of clinical settings [as previously reviewed $(149,150)$ ]. Reactivation is seen secondary to immunosuppressive therapy for cancer, in particular in the context of therapy with rituximab and fludarabine $(33,151)$, solid organ transplantation (150), bone marrow transplantation (152), and autoimmune disease [especially with infliximab treatment (153-155)], highlighting that $\mathrm{HBV}$ reactivation is associated with a general defect of $\mathrm{HBV}$ specific T cell control. Reactivation has also been documented in immunocompetent patients despite the presence of neutralizing antibodies (156).

Specific mutations associated with $\mathrm{HBV}$ reactivation have been identified in both neutralizing antibody targets and $\mathrm{T}$ cell epitopes (32-34). In a study of 29 patients with HBV reactivation, $75 \%$ of HBV-reactivated patients (vs $3 \%$ of chronic HBV controls) carried HBsAg mutations localized in immune-active $\mathrm{HBsAg}$ regions, and 5 of 13 identified $\mathrm{HBs} A g$ mutations were localized in HLA-restricted T cell epitopes [either class I (sC48G, sV96A, sL175S, and sG185E) or class II (sS171F)] (32). This suggests that in addition to an iatrogenic trigger for reactivation during immunosuppressive therapy, viral sequence can be a contributory factor as a result of CD8+ immune escape mutants. 


\section{Impact of Host HLA Class I Haplotype on HBV Infection Outcome}

GWAS approaches have linked various single-nucleotide polymorphisms in the HLA class II region with a range of infection outcomes, but there is a lack of such robust evidence for the involvement of HLA class I genes $(72,73,75)$. One study identified a relationship between class I HLA-A genotype and $\mathrm{HBeAg}$ status (66), suggesting a role for genes at this locus in control of infection. However, confirmation of HLA associations can be difficult due to the variability in study design and methodologies and the small, heterogeneous populations sampled. Furthermore, the mechanisms for these HLA class I associations with disease outcome are poorly understood. Differences in antigen presentation, TCR binding leading to changes in $\mathrm{T}$ cell activation, and altered cytokine production may be responsible, either individually or in combination. Effects of linkage disequilibrium with other important neighboring loci, such as HLA class II or killer-cell immunoglobulin-like receptors genes, cannot be excluded. Functional studies are required to determine the basis for these associations.

\section{Impact of HBV Adaptation on Control Strategies}

It is likely that to achieve elimination in line with global public health goals (157), new therapies targeting either the host immune system or the HBV replication cycle will be needed. Specific immunotherapies are under development, targeting both the innate and adaptive immune system, which aim to eliminate (or stably suppress) HBV replication (158).

T cell-based immune therapies are attractive options for HBV control (159). Strategies broadly take two approaches, either aiming to restore functionality and increase the quantity of existing defective host $\mathrm{T}$ cells with vaccines and checkpoint inhibitors, or to mimic the $\mathrm{T}$ cell response mounted during naturally resolving acute HBV infection by the adoptive transfer of HBV-specific $\mathrm{T}$ cells. Adoptive $\mathrm{T}$ cell therapy renders $\mathrm{T}$ cells HBV-specific by expression of natural HLA-restricted TCRs or HLA-independent chimeric antigen receptors on the $\mathrm{T}$ cell surface. Although natural TCRs have the advantage of activating the $\mathrm{T}$ cell response in a physiological way, therapy is potentially complicated by the need to match TCR to host HLA alleles, although some cross-reactivity may occur (160).

Given that HBV is able to evade natural immunity $(32,149$, $156,161,162)$, vaccine-induced immunity $(163,164)$, and antiviral therapy $(145,165-169)$, it should be anticipated that $\mathrm{HBV}$ has the potential to mutate and escape from immunotherapeutic control. This is a vital consideration in the development of new HBV control strategies, and good knowledge of the full range of escape strategies should allow us to predict and potentially mitigate this. Care must be taken when developing $\mathrm{T}$ cell immunotherapies and polyepitope vaccines as immunodominance is a complex function of the nature and context of the epitope within the peptide, the TCR, the T cell clone, and the environment (98). The HBV literature is skewed toward the investigation of certain populations with specific HBV genotypes and HLA haplotypes, as highlighted in the "Hepitopes" database, a catalog of HLA class I epitopes in HBV, in which a disproportionate $44 \%$ of reported CD8+ $\mathrm{T}$ cell epitopes are HLA-A ${ }^{\star} 02$ restricted (53). The effect of using a polyepitope vaccine or re-directing $\mathrm{T}$ cells against peptides presented by discordant HLA alleles needs to be considered. This might inadvertently occur by using a vaccine or $\mathrm{T}$ cellbased immunotherapy based on key epitopes from a different genotype to that prevalent in the population to which it is

TABLE 2 | Areas for future focus in determining the nature and characteristics of the CD8+ T cell response to hepatitis B virus (HBV).

Approach
Comprehensive case-finding and diagnostic strategy
Matched host genetic, clinical outcome and viral sequencing data, from
populations with varying human leukocyte antigen $(H\llcorner A)$ alleles and different
infecting HBV genotypes, supported by improved case-finding strategy

Next generation sequencing of full-length HBV genome, including longitudinal deep sequencing data

Culture systems for autologous HBV

\section{Rationale}

To build a more complete picture of global HBV prevalence and distribution

To study the differential impact of viral and host genetics on host outcome. An unbiased approach is required to determine HLA genes that may be associated with specific clinical outcomes

To investigate mechanisms behind reactivation in the immunosuppressed

To study the kinetics of viral transmission, evolution and escape, and the role played by viral quasispecies - higher sensitivity for low-abundance variant detection

To identify novel mechanisms for CD8+ immune escape, e.g., antigen-processing escape mutants, regulation of HLA expression, N-linked glycosylation (Figure 3)

To allow functional impact of patient-isolated HBV mutant strains to be studied, to determine fitness impact of the primary mutation, "mirror mutations" and compensatory mutations on replication, transmission, drug resistance immunogenicity, and clinical outcomes

Determination of 3D crystal structures for HBV proteins To allow assessment of structural impact of viral polymorphisms, including consequences of immune and drug-mediated escape mutations

Comprehensive functional $\mathrm{T}$ cell studies

To understand how HLA class I escape mutants impact T cell function and the impact of viral and host genotype

Compartment-specific sampling to include liver and lymphoid tissue
To determine the presence of replication and transmission competent compartment-specific mutants and their dynamics including emergence of immune and antiviral escape mutants 
delivered, and may produce functionally incompetent $\mathrm{T}$ cells, unable to recognize the infectious virus strain when used, or potentially lead to immunopathology. Since knowledge about certain host/virus interactions is under-represented, further studies will be required to define the full range of CD8+ T cell epitopes presented by HLA alleles, the antiviral functions of the corresponding CD8+ T cells in each compartment, the potential for generation of immune escape mutants and the impact these have on the immune response.

\section{CHALLENGES}

The understanding of HBV escape from the CD8+ immune response is lagging behind that of HIV and HCV. The field struggles with a lack of comprehensive literature, small datasets that can lead to conflicting results, differences in approaches to classifying patient groups into poor/outdated descriptions of "phases" of infection, over-reliance on serostatus, and lack of longitudinal follow-up and deep sequence data. Establishing the role of compartmentalization in infection is complex, with clinical samples scarce due to the risk associated with liver biopsy. These challenges are exacerbated by an under-resourcing of clinical and research approaches in many of the settings where HBV is endemic (8).

\section{FUTURE FOCUS}

There are many unanswered questions in the field of HBV and CD8+ immunity. In Table 2, we highlight gaps in our current understanding and knowledge, suggest desirable methods to develop, datasets to collate, and questions to be answered in order to provide foundations for ongoing research efforts.

\section{REFERENCES}

1. Polaris Observatory Collaborators. Global prevalence, treatment, and prevention of hepatitis B virus infection in 2016: a modelling study. Lancet Gastroenterol Hepatol (2018) 3(6):383-403. doi:10.1016/S2468-1253 (18)30056-6

2. Pult I, Abbott N, Zhang YY, Summers J. Frequency of spontaneous mutations in an avian hepadnavirus infection. J Virol (2001) 75(20):9623-32. doi:10.1128/JVI.75.20.9623-9632.2001

3. Whalley SA, Murray JM, Brown D, Webster GJ, Emery VC, Dusheiko GM, et al. Kinetics of acute hepatitis B virus infection in humans. J Exp Med (2001) 193:847-54. doi:10.1084/jem.193.7.847

4. Sheldon J, Soriano V. Hepatitis B virus escape mutants induced by antiviral therapy. J Antimicrob Chemother (2008) 61(4):766-8. doi:10.1093/jac/ dkn014

5. Mizokami M, Orito E, Ohba K, Ikeo K, Lau JYN, Gojobori T. Constrained evolution with respect to gene overlap of hepatitis B virus. J Mol Evol (1997) 44(1 Suppl):83-90. doi:10.1007/PL00000061

6. Harrison A, Lemey P, Hurles M, Moyes C, Horn S, Pryor J, et al. Genomic analysis of hepatitis B virus reveals antigen state and genotype as sources of evolutionary rate variation. Viruses (2011) 3(2):83-101. doi:10.3390/ v3020083

7. Hayer J, Jadeau F, Deléage G, Kay A, Zoulim F, Combet C. The Hepatitis B Virus Database (HBVdb) - X02763 [Internet]. Available from: https://hbvdb. ibcp.fr (Accessed: April, 2018).

8. O’Hara GA, McNaughton AL, Maponga T, Jooste P, Ocama P, Chilengi R, et al. Hepatitis B virus infection as a neglected tropical disease. PLoS Negl Trop Dis (2017) 11(10):e0005842. doi:10.1371/journal.pntd.0005842

\section{SUMMARY}

Hepatitis B virus is a complicated, unique virus, which has evolved together with Homo sapiens over millennia; it has evolved a range of mechanisms that favor transmission and persistence which include the capacity to evade the CD8+ T cell response. By focusing on understanding the evolutionary interplay between host and virus, we can develop better insights into areas where we can target viral "Achilles heels." The need for novel anti-HBV strategies should drive a deeper exploration of this host-pathogen interaction. Future research will be strengthened by comprehensive cross-sectional and longitudinal studies on HLA-typed hosts with clinical details, across a range of host ethnicities and HBV genotypes, with high quality serological and whole genome HBV deep sequencing data. This will provide a more comprehensive understanding of the nature and mechanisms of $\mathrm{HBV}$ evolution and persistence, helping us to reach the goal of global HBV eradiation by guiding the design of new strategies, including vaccines and therapeutics.

\section{AUTHOR CONTRIBUTIONS}

SL undertook the primary literature review and drafted the manuscript; all authors had substantial input into revisions.

\section{FUNDING}

SL is funded by the National Institute for Health Research. PM is funded by the Wellcome Trust (grant number 110110). KL is funded by the Wellcome Trust (grant number 107652/Z15/Z) and The Royal Society. PK is funded by the Wellcome Trust (WT109965MA) and National Institute for Health Research Biomedical Research Centre, Oxford.

9. Rehermann B, Fowler P, Sidney J, Person J, Redeker A, Brown M, et al. The cytotoxic $\mathrm{T}$ lymphocyte response to multiple hepatitis B virus polymerase epitopes during and after acute viral hepatitis. J Exp Med (1995) 181(3):1047-58. doi:10.1084/jem.181.3.1047

10. Chen MT, Billaud J-N, Sällberg M, Guidotti LG, Chisari FV, Jones J, et al. A function of the hepatitis B virus precore protein is to regulate the immune response to the core antigen. Proc Natl Acad Sci U S A (2004) 101(41):14913-8. doi:10.1073/pnas.0406282101

11. Streeck H, Nixon DF. T cell immunity in acute HIV-1 infection. J Infect Dis (2010) 202(Suppl 2):S302-8. doi:10.1086/655652

12. McBrien JB, Kumar NA, Silvestri G. Mechanisms of CD8(+) T cell-mediated suppression of HIV/SIV replication. Eur J Immunol (2018) 48(6):898-914. doi:10.1002/eji.201747172

13. Hoh A, Heeg M, Ni Y, Schuch A, Binder B, Hennecke N, et al. HBV-infected HepG2hNTCP cells serve as a novel immunological tool to analyze the antiviral efficacy of CD8+ T cells in vitro. J Virol (2015) 89(14):7433-8. doi:10.1128/JVI.00605-15

14. Frank I, Budde C, Fiedler M, Dahmen U, Viazov S, Lu M, et al. Acute resolving woodchuck hepatitis virus (WHV) infection is associated with a strong cytotoxic T-lymphocyte response to a single WHV core peptide. J Virol (2007) 81(13):7156-63. doi:10.1128/JVI.02711-06

15. Jo J, Aichele U, Kersting N, Klein R, Aichele P, Bisse E, et al. Analysis of $\mathrm{CD} 8+\mathrm{T}$-cell-mediated inhibition of hepatitis $\mathrm{C}$ virus replication using a novel immunological model. Gastroenterology (2009) 136(4):1391-401. doi:10.1053/j.gastro.2008.12.034

16. Billerbeck E, Wolfisberg R, Fahnøe U, Xiao JW, Quirk C, Luna JM, et al. Mouse models of acute and chronic hepacivirus infection. Science (2017) 357(6347):204-8. doi:10.1126/science.aal1962 
17. Julg B, Williams KL, Reddy S, Bishop K, Qi Y, Carrington M, et al. Enhanced anti-HIV functional activity associated with gag-specific CD8 T-cell responses. J Virol (2010) 84(11):5540-9. doi:10.1128/JVI.02031-09

18. Thimme R, Wieland S, Steiger C, Ghrayeb J, Reimann KA, Purcell RH, et al. CD8(+) T cells mediate viral clearance and disease pathogenesis during acute hepatitis B virus infection. J Virol (2003) 77(1):68-76. doi:10.1128/ JVI.77.1.68-76.2003

19. Shoukry NH, Grakoui A, Houghton M, Chien DY, Ghrayeb J, Reimann KA, et al. Memory CD8+ T cells are required for protection from persistent hepatitis C virus infection. J Exp Med (2003) 197(12):1645-55. doi:10.1084/jem. 20030239

20. Leitman EM, Palmer CD, Buus S, Chen F, Riddell L, Sims S, et al. Saporinconjugated tetramers identify efficacious anti-HIV CD8+ T-cell specificities. PLoS One (2017) 12(10):e0184496. doi:10.1371/journal.pone.0184496

21. Jin X, Bauer DE, Tuttleton SE, Lewin S, Gettie A, Blanchard J, et al. Dramatic rise in plasma viremia after CD8(+) T cell depletion in simian immunodeficiency virus-infected macaques. J Exp Med (1999) 189(6):991-8. doi:10.1084/ jem.189.6.991

22. Bertoletti A, Ferrari C. Adaptive immunity in HBV infection. J Hepatol (2016) 64(1):S71-83. doi:10.1016/j.jhep.2016.01.026

23. Boni C, Fisicaro P, Valdatta C, Amadei B, Di Vincenzo P, Giuberti T, et al. Characterization of hepatitis B virus (HBV)-specific T-cell dysfunction in chronic HBV infection. J Virol (2007) 81(8):4215-25. doi:10.1128/JVI. 02844-06

24. Chang JJ, Thompson AJV, Visvanathan K, Kent SJ, Cameron PU, Wightman F, et al. The phenotype of hepatitis B virus-specific $\mathrm{T}$ cells differ in the liver and blood in chronic hepatitis B virus infection. Hepatology (2007) 46(5):1332-40. doi:10.1002/hep.21844

25. PhillipsS, ChokshiS, Riva A, Evans A, WilliamsR, NaoumovNV.CD8(+) Tcell control of hepatitis B virus replication: direct comparison between cytolytic and noncytolytic functions. J Immunol (2010) 184(1):287-95. doi:10.4049/ jimmunol.0902761

26. Fisicaro P, Valdatta C, Massari M, Loggi E, Biasini E, Sacchelli L, et al. Antiviral intrahepatic T-cell responses can be restored by blocking programmed death-1 pathway in chronic hepatitis B. Gastroenterology (2010) 138(2):682-93. doi:10.1053/j.gastro.2009.09.052

27. Cao H, Zhang R, Zhang W. CTLA4 interferes with the HBV specific $\mathrm{T}$ cell immune response (review). Int J Mol Med (2018) 42(2):703-12. doi:10.3892/ ijmm.2018.3688

28. Schurich A, Khanna P, Lopes AR, Han KJ, Peppa D, Micco L, et al. Role of the coinhibitory receptor cytotoxic T lymphocyte antigen-4 on apoptosisprone CD8 T cells in persistent hepatitis B virus infection. Hepatology (2011) 53(5):1494-503. doi:10.1002/hep.24249

29. Wu W, Shi Y, Li S, Zhang Y, Liu Y, Wu Y, et al. Blockade of Tim-3 signaling restores the virus-specific CD8 + T-cell response in patients with chronic hepatitis B. Eur J Immunol (2012) 42(5):1180-91. doi:10.1002/eji. 201141852

30. Rutebemberwa A, Ray SC, Astemborski J, Levine J, Liu L, Dowd KA, et al. High-programmed death-1 levels on hepatitis $C$ virus-specific $T$ cells during acute infection are associated with viral persistence and require preservation of cognate antigen during chronic infection. J Immunol (2008) 181(12): 8215-25. doi:10.4049/jimmunol.181.12.8215

31. Day CL, Kaufmann DE, Kiepiela P, Brown JA, Moodley ES, Reddy S, et al. $\mathrm{PD}-1$ expression on HIV-specific T cells is associated with T-cell exhaustion and disease progression. Nature (2006) 443(7109):350-4. doi:10.1038/ nature 05115

32. Salpini R, Colagrossi L, Bellocchi MC, Surdo M, Becker C, Alteri C, et al. Hepatitis B surface antigen genetic elements critical for immune escape correlate with hepatitis B virus reactivation upon immunosuppression. Hepatology (2015) 61(3):823-33. doi:10.1002/hep.27604

33. Hayashi K, Ishigami M, Ishizu Y, Kuzuya T, Honda T, Tachi Y, et al. Clinical characteristics and molecular analysis of hepatitis $B$ virus reactivation in hepatitis B surface antigen-negative patients during or after immunosuppressive or cytotoxic chemotherapy. J Gastroenterol (2016) 51(11):1081-9. doi:10.1007/s00535-016-1187-z

34. Ando T, Kojima K, Isoda H, Eguchi Y, Honda T, Ishigami M, et al. Reactivation of resolved infection with the hepatitis $\mathrm{B}$ virus immune escape mutant G145R during dasatinib treatment for chronic myeloid leukemia. Int J Hematol (2015) 102(3):379-82. doi:10.1007/s12185-015-1788-y
35. Cartwright EK, Spicer L, Smith SA, Lee D, Fast R, Paganini S, et al. CD8(+) lymphocytes are required for maintaining viral suppression in SIV-infected macaques treated with short-term antiretroviral therapy. Immunity (2016) 45(3):656-68. doi:10.1016/j.immuni.2016.08.018

36. Deng K, Pertea M, Rongvaux A, Wang L, Durand CM, Ghiaur G, et al. Broad CTL response is required to clear latent HIV-1 due to dominance of escape mutations. Nature (2015) 517(7534):381-5. doi:10.1038/nature14053

37. Pignatelli M, Waters J, Brown D, Lever A, Iwarson S, Schaff Z, et al. HLA class I antigens on the hepatocyte membrane during recovery from acute hepatitis $B$ virus infection and during interferon therapy in chronic hepatitis $B$ virus infection. Hepatology (1986) 6(3):349-53. doi:10.1002/hep.1840060303

38. Chu CM, Shyu WC, Kuo RW, Liaw YF. HLA class I antigen display on hepatocyte membrane in chronic hepatitis B virus infection: its role in the pathogenesis of chronic type B hepatitis. Hepatology (1987) 8(3):712-7. doi:10.1002/hep. 1840080358

39. Montanto L, Miescher GC, Goodall AH, Wiedmann KH, Janossy G, Thomas HC. Hepatitis B virus and HLA antigen display in the liver during chronic hepatitis B virus infection. Hepatology (1982) 2(5):557S-61S. doi:10.1002/ hep. 1840020508

40. Michalak TI, Hodgson PD, Churchill ND. Posttranscriptional inhibition of class I major histocompatibility complex presentation on hepatocytes and lymphoid cells in chronic woodchuck hepatitis virus infection. J Virol (2000) 74(10):4483-94. doi:10.1128/JVI.74.10.4483-4494.2000

41. Saito K, Ait-Goughoulte M, Truscott SM, Meyer K, Blazevic A, Abate G, et al. Hepatitis $C$ virus inhibits cell surface expression of HLA-DR, prevents dendritic cell maturation, and induces interleukin-10 production. $J$ Virol (2008) 82(7):3320-8. doi:10.1128/JVI.02547-07

42. Kang W, Sung PS, Park S-H, Yoon S, Chang D-Y, Kim S, et al. Hepatitis C virus attenuates interferon-induced major histocompatibility complex class I expression and decreases CD8+ T cell effector functions. Gastroenterology (2014) 146(5):1351-4. doi:10.1053/j.gastro.2014.01.054

43. Schwartz O, Maréchal V, Le Gall S, Lemonnier F, Heard JM. Endocytosis of major histocompatibility complex class I molecules is induced by the HIV-1 Nef protein. Nat Med (1996) 2(3):338-42. doi:10.1038/nm0396-338

44. Mwimanzi P, Markle TJ, Ueno T, Brockman MA. Human leukocyte antigen (HLA) class I down-regulation by human immunodeficiency virus type 1 negative factor (HIV-1 Nef): what might we learn from natural sequence variants? Viruses (2012) 4(9):1711-30. doi:10.3390/v4102014

45. Backes S, Jäger C, Dembek CJ, Kosinska AD, Bauer T, Stephan AS, et al. Protein-prime/modified vaccinia virus Ankara vector-boost vaccination overcomes tolerance in high-antigenemic HBV-transgenic mice. Vaccine (2016) 34(7):923-32. doi:10.1016/j.vaccine.2015.12.060

46. Buchmann P, Dembek C, Kuklick L, Jäger C, Tedjokusumo R, von Freyend MJ, et al. A novel therapeutic hepatitis B vaccine induces cellular and humoral immune responses and breaks tolerance in hepatitis B virus (HBV) transgenic mice. Vaccine (2013) 31(8):1197-203. doi:10.1016/j.vaccine.2012.12.074

47. Kosinska AD, Zhang E, Johrden L, Liu J, Seiz PL, Zhang X, et al. Combination of DNA prime - adenovirus boost immunization with entecavir elicits sustained control of chronic hepatitis B in the woodchuck model. PLoS Pathog (2013) 9(6):e1003391. doi:10.1371/journal.ppat.1003391

48. Wijesundara DK, Gummow J, Li Y, Yu W, Quah BJ, Ranasinghe C, et al. Induction of genotype cross-reactive, hepatitis $\mathrm{C}$ virus-specific cell-mediated immunity in DNA-vaccinated mice. J Virol (2018) 92(8):e02133-17. doi:10.1128/JVI.02133-17

49. von Delft A, Donnison TA, Lourenço J, Hutchings C, Mullarkey CE, Brown A, et al. The generation of a simian adenoviral vectored $\mathrm{HCV}$ vaccine encoding genetically conserved gene segments to target multiple HCV genotypes. Vaccine (2018) 36(2):313-21. doi:10.1016/j.vaccine.2017.10.079

50. Barouch DH, O’Brien KL, Simmons NL, King SL, Abbink P, Maxfield LF, et al. Mosaic HIV-1 vaccines expand the breadth and depth of cellular immune responses in rhesus monkeys. Nat Med (2010) 16(3):319-23. doi:10.1038/ nm.2089

51. Mcmichael AJ, Koff WC. Vaccines that stimulate T cell immunity to HIV-1: the next step. Nat Immunol (2014) 15(4):319-22. doi:10.1038/ni.2844

52. Streeck H. Designing optimal HIV-vaccine T-cell responses. Curr Opin HIV AIDS (2016) 11(6):593-600. doi:10.1097/COH.0000000000000313

53. Lumley S, Noble H, Hadley MJ, Callow L, Malik A, Chua YY, et al. Hepitopes: a live interactive database of HLA class I epitopes in hepatitis B virus. Wellcome Open Res (2016) 1:9. doi:10.12688/wellcomeopenres.9952.1 
54. Kefalakes H, Budeus B, Walker A, Jochum C, Hilgard G, Heinold A, et al. Adaptation of the hepatitis B virus core protein to CD8 + T-cell selection pressure. Hepatology (2015) 62(1):47-56. doi:10.1002/hep.27771

55. Nitschke K, Luxenburger H, Kiraithe MM, Thimme R, Neumann-Haefelin C. CD8+ T-cell responses in hepatitis B and C: the (HLA-) A, B, and C of hepatitis B and C. Dig Dis (2016) 34(4):396-409. doi:10.1159/000444555

56. Desmond CP, Gaudieri S, James IR, Pfafferott K, Chopra A, Lau GK, et al. Viral adaptation to host immune responses occurs in chronic hepatitis B virus (HBV) infection, and adaptation is greatest in $\mathrm{HBV}$ e antigen-negative disease. J Virol (2012) 86(2):1181-92. doi:10.1128/JVI.05308-11

57. Abbott WGH, Tsai P, Leung E, Trevarton A, Ofanoa M, Hornell J, et al. Associations between HLA class I alleles and escape mutations in the hepatitis B virus core gene in New Zealand-resident Tongans. J Virol (2010) 84(1):621-9. doi:10.1128/JVI.01471-09

58. Khedive A, Norouzi M, Ramezani F, Karimzadeh H, Alavian SM, Malekzadeh R, et al. Hepatitis B virus surface protein mutations clustered mainly in CTL immune epitopes in chronic carriers: results of an Iranian nationwide study. J Viral Hepat (2013) 20(7):494-501. doi:10.1111/jvh.12045

59. Nassal M, Dallmeier K, Schultz U, Sun D. Phenotyping hepatitis B virus variants: from transfection towards a small animal in vivo infection model. J Clin Virol (2005) 34(Suppl 1):S89-95. doi:10.1016/S1386-6532(05)80017-4

60. Gaudieri S, Rauch A, Park LP, Freitas E, Herrmann S, Jeffrey G, et al. Evidence of viral adaptation to HLA class I-restricted immune pressure in chronic hepatitis C virus infection. J Virol (2006) 80(22):11094-104. doi:10.1128/JVI. 00912-06

61. Fitzmaurice K, Petrovic D, Ramamurthy N, Simmons R, Merani S, Gaudieri S, et al. Molecular footprints reveal the impact of the protective HLA-A ${ }^{*} 03$ allele in hepatitis C virus infection. Gut (2011) 60(11):1563-71. doi:10.1136/ gut.2010.228403

62. Ruhl M, Knuschke T, Schewior K, Glavinic L, Neumann-Haefelin C, Chang DI, et al. CD8+ T-cell response promotes evolution of hepatitis $\mathrm{c}$ virus nonstructural proteins. Gastroenterology (2011) 140(7):2064-73. doi:10.1053/j. gastro.2011.02.060

63. Kloverpris HN, Leslie A, Goulder P. Role of HLA adaptation in HIV evolution. Front Immunol (2015) 6:665. doi:10.3389/fimmu.2015.00665

64. Martins MA, Tully DC, Cruz MA, Power KA, Veloso de Santana MG, Bean DJ, et al. Vaccine-induced simian immunodeficiency virus-specific $\mathrm{CD}^{+} \mathrm{T}$-cell responses focused on a single Nef epitope select for escape variants shortly after infection. J Virol (2015) 89(21):10802-20. doi:10.1128/ JVI.01440-15

65. Harris M, Burns CM, Becker EA, Braasch AT, Gostick E, Johnson RC, et al. Acute-phase CD8 $\mathrm{T}$ cell responses that select for escape variants are needed to control live attenuated simian immunodeficiency virus. J Virol (2013) 87(16):9353-64. doi:10.1128/JVI.00909-13

66. Matthews PC, Carlson JM, Beloukas A, Malik A, Jooste P, Ogwu A, et al. HLA-A is a predictor of hepatitis B e antigen status in HIV-positive African adults. J Infect Dis (2016) 213(8):1248-52. doi:10.1093/infdis/jiv592

67. McKiernan SM, Hagan R, Curry M, McDonald GSA, Kelly A, Nolan N, et al. Distinct MHC class I and II alleles are associated with hepatitis $\mathrm{C}$ viral clearance, originating from a single source. Hepatology (2004) 40(1):108-14. doi:10.1002/hep.20261

68. Kiepiela P, Leslie AJ, Honeyborne I, Ramduth D, Thobakgale C, Chetty S, et al. Dominant influence of HLA-B in mediating the potential co-evolution of HIV and HLA. Nature (2004) 432(7018):769-75. doi:10.1038/nature03113

69. Martinez-Picado J, Prado JG, Fry EE, Pfafferott K, Leslie A, Chetty S, et al. Fitness cost of escape mutations in $\mathrm{p} 24 \mathrm{Gag}$ in association with control of human immunodeficiency virus type 1. J Virol (2006) 80(7):3617-23. doi:10.1128/ JVI.80.7.3617-3623.2006

70. Kiepiela P, Ngumbela K, Thobakgale C, Ramduth D, Honeyborne I, Moodley E, et al. CD8+T-cell responses to different HIV proteins have discordant associations with viral load. Nat Med (2007) 13(1):46-53. doi: $10.1038 / \mathrm{nm} 1520$

71. Frater AJ, Brown H, Oxenius A, Gunthard HF, Hirschel B, Robinson N, et al. Effective T-cell responses select human immunodeficiency virus mutants and slow disease progression. J Virol (2007) 81(12):6742-51. doi:10.1128/ JVI.00022-07

72. Singh R, Kaul R, Kaul A, Khan K. A comparative review of HLA associations with hepatitis B and C viral infections across global populations. World J Gastroenterol (2007) 13(12):1770-87. doi:10.3748/wjg.v13.i12.1770
73. Wang L, Zou ZQ, Wang K. Clinical relevance of HLA gene variants in HBV infection. J Immunol Res (2016) 2016:9069375. doi:10.1155/2016/9069375

74. Li X, Liu W, Wang H, Jin X, Fang S, Shi Y, et al. The influence of HLA alleles and HBV subgenotyes on the outcomes of HBV infections in Northeast China. Virus Res (2012) 163(1):328-33. doi:10.1016/j.virusres.2011.10.020

75. Thio CL, Thomas DL, Karacki P, Gao X, Marti D, Kaslow RA, et al. Comprehensive analysis of class I and class II HLA antigens and chronic hepatitis B virus infection. J Virol (2003) 77(22):12083-7. doi:10.1128/JVI.77.22. 12083-12087.2003

76. Ansari MA, Pedergnana V, Ip C LC, Magri A, Von Delft A, Bonsall D, et al. Genome-to-genome analysis highlights the effect of the human innate and adaptive immune systems on the hepatitis C virus. Nat Genet (2017) 49(5):666-73. doi:10.1038/ng.3835

77. Neumann-Haefelin C, Oniangue-Ndza C, Kuntzen T, Schmidt J, Nitschke K, Sidney J, et al. Human leukocyte antigen B27 selects for rare escape mutations that significantly impair hepatitis $\mathrm{C}$ virus replication and require compensatory mutations. Hepatology (2011) 54(4):1157-66. doi:10.1002/ hep. 24541

78. Fellay J, Shianna KV, Ge D, Colombo S, Ledergerber B, Weale M, et al. A whole-genome association study of major determinants for host control of HIV-1. Science (2007) 317(5840):944-7. doi:10.1126/science.1143767

79. International HIV Controllers Study, Pereyra F, Jia X, McLaren PJ, Telenti A, De Bakker PIW, et al. The major genetic determinants of HIV-1 control affect HLA class I peptide presentation. Science (2010) 330(6010):1551-7. doi:10.1126/science.1195271

80. Penna A, Del Prete G, Cavalli A, Bertoletti A, D’Elios MM, Sorrentino R, et al. Predominant T-helper 1 cytokine profile of hepatitis B virus nucleocapsid-specific T cells in acute self-limited hepatitis B. Hepatology (1997) 25(4):1022-7. doi:10.1002/hep.510250438

81. Nishida N, Sugiyama M, Sawai H, Nishina S, Sakai A, Ohashi J, et al. Key HLA-DRB1-DQB1 haplotypes and role of the BTNL2 gene for response to a hepatitis B vaccine. Hepatology (2018). doi:10.1002/hep.29876

82. Hu Z, Liu Y, Zhai X, Dai J, Jin G, Wang L, et al. New loci associated with chronic hepatitis B virus infection in Han Chinese. Nat Genet (2013) 45(12):1499-503. doi:10.1038/ng.2809

83. Kamatani Y, Wattanapokayakit S, Ochi H, Kawaguchi T, Takahashi A, Hosono $\mathrm{N}$, et al. A genome-wide association study identifies variants in the HLA-DP locus associated with chronic hepatitis B in Asians. Nat Genet (2009) 41(5):591-5. doi:10.1038/ng.348

84. Hosaka T, Suzuki F, Kobayashi M, Fukushima T, Kawamura Y, Sezaki H, et al. HLA-DP genes polymorphisms associate with hepatitis B surface antigen kinetics and seroclearance during nucleot(s)ide analogue therapy. Liver Int (2015) 35(4):1290-302. doi:10.1111/liv.12652

85. Jiang D-K, Sun J, Cao G, Liu Y, Lin D, Gao Y-Z, et al. Genetic variants in STAT4 and HLA-DQ genes confer risk of hepatitis B virus-related hepatocellular carcinoma. Nat Genet (2013) 45(1):72-5. doi:10.1038/ng.2483

86. Stoop JN, Van Der Molen RG, Baan CC, Van Der Laan LJW, Kuipers EJ, Kusters JG, et al. Regulatory $\mathrm{T}$ cells contribute to the impaired immune response in patients with chronic hepatitis B virus infection. Hepatology (2005) 41(4):771-8. doi:10.1002/hep.20649

87. Feng I-C, Koay L-B, Sheu M-J, Kuo H-T, Sun C-S, Lee C, et al. HBcAg-specific $\mathrm{CD} 4+\mathrm{CD} 25+$ regulatory $\mathrm{T}$ cells modulate immune tolerance and acute exacerbation on the natural history of chronic hepatitis B virus infection. J Biomed Sci (2007) 14(1):43-57. doi:10.1007/s11373-006-9129-z

88. Lin C-L, Kao J-H. Natural history of acute and chronic hepatitis B: the role of HBV genotypes and mutants. Best Pract Res Clin Gastroenterol (2017) 31(3):249-55. doi:10.1016/j.bpg.2017.04.010

89. Fung SK, Lok ASF. Hepatitis B virus genotypes: do they play a role in the outcome of HBV infection? Hepatology (2004) 40(4):790-2. doi:10.1002/ hep. 20455

90. Matsuura K, Isogawa M, Tanaka Y. Host genetic variants influencing the clinical course of hepatitis B virus infection. J Med Virol (2016) 88(3):371-9. doi:10.1002/jmv.24350

91. El-Serag HB. Epidemiology of viral hepatitis and hepatocellular carcinoma. Gastroenterology (2012) 142(6):1264-73. doi:10.1053/j.gastro.2011. 12.061

92. Cresswell P, Ackerman AL, Giodini A, Peaper DR, Wearsch PA. Mechanisms of MHC class I-restricted antigen processing and cross-presentation. Immunol Rev (2005) 207:145-57. doi:10.1111/j.0105-2896.2005.00316.x 
93. Bromley SK, Burack WR, Kenneth G, Somersalo K, Sims TN, Sumen C, et al. The immunological synapse. Annu Rev Immunol (2001) 19:375-96. doi:10.1146/annurev.immunol.19.1.375

94. Klenerman P, McMichael A. AIDS/HIV. Finding footprints among the trees. Science (2007) 315(5818):1505-7. doi:10.1126/science.1140768

95. Yu DM, Li XH, Mom V, Lu ZH, Liao XW, Han Y, et al. N-glycosylation mutations within hepatitis B virus surface major hydrophilic region contribute mostly to immune escape. J Hepatol (2014) 60(3):515-22. doi:10.1016/j. jhep.2013.11.004

96. Bertoletti A, Costanzo A, Chisari FV, Levrero M, Artini M, Sette A, et al. Cytotoxic $\mathrm{T}$ lymphocyte response to a wild type hepatitis $\mathrm{B}$ virus epitope in patients chronically infected by variant viruses carrying substitutions within the epitope. J Exp Med (1994) 180(3):933-43. doi:10.1084/jem.180.3.933

97. Bertoletti A, Sette A, Chisari FV, Penna A, Levrero M, De Carli M, et al. Natural variants of cytotoxic epitopes are T-cell receptor antagonists for antiviral cytotoxic T cells. Nature (1994) 369(6479):407-10. doi:10.1038/ $369407 \mathrm{a} 0$

98. Nayersina R, Fowler P, Guilhot S, Missale G, Cerny A, Schlicht HJ, et al. HLA A2 restricted cytotoxic T lymphocyte responses to multiple hepatitis B surface antigen epitopes during hepatitis B virus infection. JImmunol (1993) 150(10):4659-71.

99. Chen M, Sällberg M, Hughes J, Jones J, Guidotti LG, Chisari FV, et al. Immune tolerance split between hepatitis B virus precore and core proteins. J Virol (2005) 79(5):3016-27. doi:10.1128/JVI.79.5.3016-3027.2005

100. Kimura Y, Gushima T, Rawale S, Kaumaya P, Walker CM. Escape mutations alter proteasome processing of major histocompatibility complex class I-restricted epitopes in persistent hepatitis C virus infection. J Virol (2005) 79(8):4870-6. doi:10.1128/JVI.79.8.4870-4876.2005

101. Allen TM, Altfeld M, Yu XG, O’Sullivan KM, Lichterfeld M, Le Gall S, et al. Selection, transmission, and reversion of an antigen-processing cytotoxic T-lymphocyte escape mutation in human immunodeficiency virus type 1 infection. J Virol (2004) 78(13):7069-78. doi:10.1128/JVI.78.13.70697078.2004

102. Mohamadkhani A, Sotoudeh M, Bowden S, Poustchi H, Jazii FR, Sayehmiri K, et al. Downregulation of HLA class II molecules by G1896A pre-core mutation in chronic hepatitis B virus infection. Viral Immunol (2009) 22(5): 295-300. doi:10.1089/vim.2009.0031

103. Rehermann B, Pasquinelli C, Mosier SM, Chisari FV. Hepatitis B virus (HBV) sequence variation of cytotoxic $\mathrm{T}$ lymphocyte epitopes is not common in patients with chronic HBV infection. J Clin Invest (1995) 96(3):1527-34. doi:10.1172/JCI118191

104. Osiowy C, Giles E, Tanaka Y, Mizokami M, Minuk GY. Molecular evolution of hepatitis B virus over 25 years. J Virol (2006) 80(21):10307-14. doi:10.1128/ JVI.00996-06

105. Chen L, Gan QR, Zhang DQ, Yao LF, Lin RS, Li Q, et al. Increased intrahepatic quasispecies heterogeneity correlates with off-treatment sustained response to nucleos(t)ide analogues in e antigen-positive chronic hepatitis B patients. Clin Microbiol Infect (2016) 22(2):201-7. doi:10.1016/j.cmi.2015.10.007

106. Vigerust DJ, Shepherd VL. Virus glycosylation: role in virulence and immune interactions. Trends Microbiol (2007) 15(5):211-8. doi:10.1016/j. tim.2007.03.003

107. Anjum S, Wahid A, Afzal MS, Albecka A, Alsaleh K, Ahmad T, et al. Additional glycosylation within a specific hypervariable region of subtype 3a of hepatitis C virus protects against virus neutralization. J Infect Dis (2013) 208(11):1888-97. doi:10.1093/infdis/jit376

108. Kwei K, Tang X, Lok AS, Sureau C, Garcia T, Li J, et al. Impaired virion secretion by hepatitis $\mathrm{B}$ virus immune escape mutants and its rescue by wild-type envelope proteins or a second-site mutation. J Virol (2013) 87(4): 2352-7. doi:10.1128/JVI.02701-12

109. Ito K, Qin Y, Guarnieri M, Garcia T, Kwei K, Mizokami M, et al. Impairment of hepatitis B virus virion secretion by single-amino-acid substitutions in the small envelope protein and rescue by a novel glycosylation site. J Virol (2010) 84(24):12850-61. doi:10.1128/JVI.01499-10

110. Julithe R, Abou-Jaoude G, Sureau C. Modification of the hepatitis B virus envelope protein glycosylation pattern interferes with secretion of viral particles, infectivity, and susceptibility to neutralizing antibodies. J Virol (2014) 88(16):9049-59. doi:10.1128/JVI.01161-14

111. Sede M, Lopez-Ledesma M, Frider B, Pozzati M, Campos RH, Flichman D, et al. Hepatitis $\mathrm{B}$ virus depicts a high degree of conservation during the immune-tolerant phase in familiarly transmitted chronic hepatitis B infection: deep-sequencing and phylogenetic analysis. J Viral Hepat (2014) 21(9): 650-61. doi:10.1111/jvh.12196

112. Milich D, Liang TJ. Exploring the biological basis of hepatitis B e antigen in hepatitis B virus infection. Hepatology (2003) 38(5):1075-86. doi:10.1053/ jhep.2003.50453

113. Ye B, Liu X, Li X, Kong H, Tian L, Chen Y. T-cell exhaustion in chronic hepatitis B infection: current knowledge and clinical significance. Cell Death Dis (2015) 6:e1694. doi:10.1038/cddis.2015.42

114. Webster GJM, Reignat S, Brown D, Ogg GS, Jones L, Seneviratne SL, et al. Longitudinal analysis of CD8+ $\mathrm{T}$ cells specific for structural and nonstructural hepatitis B virus proteins in patients with chronic hepatitis B: implications for immunotherapy. J Virol (2004) 78(11):5707-19. doi:10.1128/ JVI.78.11.5707-5719.2004

115. Kondo Y, Ninomiya M, Kakazu E, Kimura O, Shimosegawa T. Hepatitis B surface antigen could contribute to the immunopathogenesis of hepatitis B virus infection. ISRN Gastroenterol (2013) 2013:935295. doi:10.1155/ 2013/935295

116. Whalley SA, Brown D, Webster GJM, Jacobs R, Reignat S, Bertoletti A, et al. Evolution of hepatitis B virus during primary infection in humans: transient generation of cytotoxic T-cell mutants. Gastroenterology (2004) 127(4): 1131-8. doi:10.1053/j.gastro.2004.07.004

117. Bengsch B, Martin B, Thimme R. Restoration of HBV-specific CD8+ $\mathrm{T}$ cell function by PD-1 blockade in inactive carrier patients is linked to T cell differentiation. J Hepatol (2014) 61(6):1212-9. doi:10.1016/j.jhep. 2014.07.005

118. Boni C, Laccabue D, Lampertico P, Giuberti T, Viganò M, Schivazappa S, et al. Restored function of $\mathrm{HBV}$-specific $\mathrm{T}$ cells after long-term effective therapy with nucleos(t)ide analogues. Gastroenterology (2012) 143(4): 963-73.e9. doi:10.1053/j.gastro.2012.07.014

119. Boni C, Penna A, Bertoletti A, Lamonaca V, Rapti I, Missale G, et al. Transient restoration of anti-viral $\mathrm{T}$ cell responses induced by lamivudine therapy in chronic hepatitis B. J Hepatol (2003) 39(4):595-605. doi:10.1016/ S0168-8278(03)00292-7

120. Rivino L, Le Bert N, Gill US, Kunasegaran K, Cheng Y, Tan DZM, et al. Hepatitis b virus-specific $\mathrm{t}$ cells associate with viral control upon nucleos(t) ide-analogue therapy discontinuation. J Clin Invest (2018) 128(2):668-81. doi:10.1172/JCI92812

121. Chu CM, Liaw YF. Chronic hepatitis B virus infection acquired in childhood: special emphasis on prognostic and therapeutic implication of delayed $\mathrm{HBeAg}$ seroconversion. J Viral Hepat (2007) 14(3):147-52. doi:10.1111/j.1365-2893. 2006.00810.x

122. Chen Y-C, Chu C-M, Liaw Y-F. Age-specific prognosis following spontaneous hepatitis $\mathrm{B}$ e antigen seroconversion in chronic hepatitis $\mathrm{B}$. Hepatology (2010) 51(2):435-44. doi:10.1002/hep.23348

123. Okamoto H, Tsuda F, Akahane Y, Sugai Y, Yoshiba M, Moriyama K, et al. Hepatitis B virus with mutations in the core promoter for an e antigennegative phenotype in carriers with antibody to e antigen. J Virol (1994) 68(12):8102-10.

124. Wang H-Y, Chien M-H, Huang H-P, Chang H-C, Wu C-C, Chen P-J, et al. Distinct hepatitis B virus dynamics in the immunotolerant and early immunoclearance phases. J Virol (2010) 84(7):3454-63. doi:10.1128/JVI. 02164-09

125. Hannoun C, Horal P, Lindh M. Long-term mutation rates in the hepatitis B virus genome. J Gen Virol (2000) 81(Pt 1):75-83. doi:10.1099/00221317-81-1-75

126. Bozkaya H, Akarca US, Ayola B, Lok ASF. High degree of conservation in the hepatitis B virus core gene during the immune tolerant phase in perinatally acquired chronic hepatitis B virus infection. J Hepatol (1997) 26(3):508-16. doi:10.1016/S0168-8278(97)80415-1

127. Philpott S, Burger H, Tsoukas C, Foley B, Anastos K, Kitchen C, et al. Human immunodeficiency virus type 1 genomic RNA sequences in the female genital tract and blood: compartmentalization and intrapatient recombination. J Virol (2005) 79(1):353-63. doi:10.1128/JVI.79.1.353-363.2005

128. Schnell G, Price RW, Swanstrom R, Spudich S. Compartmentalization and clonal amplification of HIV-1 variants in the cerebrospinal fluid during primary infection. J Virol (2010) 84(5):2395-407. doi:10.1128/JVI.01863-09

129. Roque-Afonso AM, Ducoulombier D, Di Liberto G, Kara R, Gigou M, Dussaix E, et al. Compartmentalization of hepatitis $C$ virus genotypes 
between plasma and peripheral blood mononuclear cells. J Virol (2005) 79(10):6349-57. doi:10.1128/JVI.79.10.6349-6357.2005

130. Russelli G, Pizzillo P, Iannolo G, Barbera F, Tuzzolino F, Liotta R, et al. HCV replication in gastrointestinal mucosa: potential extra-hepatic viral reservoir and possible role in HCV infection recurrence after liver transplantation. PLoS One (2017) 12(7):e0181683. doi:10.1371/journal. pone. 0181683

131. Bull ME, Heath LM, McKernan-Mullin JL, Kraft KM, Acevedo L, Hitti JE, et al. Human immunodeficiency viruses appear compartmentalized to the female genital tract in cross-sectional analyses but genital lineages do not persist over time. J Infect Dis (2013) 207(8):1206-15. doi:10.1093/infdis/ jit016

132. Michalak TI. Occult persistence and lymphotropism of hepadnaviral infection: insights from the woodchuck viral hepatitis model. Immunol Rev (2000) 174:98-111. doi:10.1034/j.1600-0528.2002.017406.x

133. Mason A, Wick M, White H, Perrillo R. Hepatitis B virus replication in diverse cell types during chronic hepatitis B virus infection. Hepatology (1993) 18(4):781-9. doi:10.1002/hep.1840180406

134. Faure-Dupuy S, Durantel D, Lucifora J. Liver macrophages: friend or foe during hepatitis B infection? Liver Int (2018). doi:10.1111/liv.13884

135. Coffin CS, Mulrooney-Cousins PM, Van Marle G, Roberts JP, Michalak TI, Terrault NA. Hepatitis B virus quasispecies in hepatic and extrahepatic viral reservoirs in liver transplant recipients on prophylactic therapy. Liver Transpl (2011) 17(8):955-62. doi:10.1002/lt.22312

136. Coffin CS, Osiowy C, Gao S, Nishikawa S, van der Meer F, van Marle G. Hepatitis B virus (HBV) variants fluctuate in paired plasma and peripheral blood mononuclear cells among patient cohorts during different chronic hepatitis B (CHB) disease phases. J Viral Hepat (2015) 22(4):416-26. doi: $10.1111 /$ jvh. 12308

137. Datta S, Panigrahi R, Biswas A, Chandra PK, Banerjee A, Mahapatra PK, et al. Genetic characterization of hepatitis B virus in peripheral blood leukocytes: evidence for selection and compartmentalization of viral variants with the immune escape G145R mutation. J Virol (2009) 83(19):9983-92. doi:10.1128/JVI.01905-08

138. Brind A, Jiang J, Samuel D, Gigou M, Feray C, Bréchot C, et al. Evidence for selection of hepatitis B mutants after liver transplantation through peripheral blood mononuclear cell infection. J Hepatol (1997) 26(2):228-35. doi:10.1016/S0168-8278(97)80035-9

139. Chakravarty R, Neogi M, Roychowdhury S, Panda CK. Presence of hepatitis B surface antigen mutant G145R DNA in the peripheral blood leukocytes of the family members of an asymptomatic carrier and evidence of its horizontal transmission. Virus Res (2002) 90(1-2):133-41. doi:10.1016/ S0168-1702(02)00147-8

140. Bagaglio S, Albarello L, Biswas P, Uberti-Foppa C, Fortis C, Morsica G. Virological pattern of hepatitis B infection in an HIV-positive man with fatal fulminant hepatitis B: a case report. JMed Case Rep (2009) 3:110. doi:10.1186/1752-1947-3-110

141. Gao S, Duan Z-P, Chen Y, van der Meer F, Lee SS, Osiowy C, et al. Compartmental HBV evolution and replication in liver and extrahepatic sites after nucleos/tide analogue therapy in chronic hepatitis B carriers. JClin Virol (2017) 94:8-14. doi:10.1016/j.jcv.2017.06.009

142. Wu C, Zhang X, Tian Y, Song J, Yang D, Roggendorf M, et al. Biological significance of amino acid substitutions in hepatitis B surface antigen (HBsAg) for glycosylation, secretion, antigenicity and immunogenicity of HBsAg and hepatitis B virus replication. J Gen Virol (2010) 91(Pt 2):483-92. doi:10.1099/ vir.0.012740-0

143. Torresi J. The virological and clinical significance of mutations in the overlapping envelope and polymerase genes of hepatitis B virus. J Clin Virol (2002) 25:97-106. doi:10.1016/S1386-6532(02)00049-5

144. Delaney WE, Yang H, Westland CE, Das K, Arnold E, Gibbs CS, et al. The hepatitis B virus polymerase mutation $\mathrm{rtV} 173 \mathrm{~L}$ is selected during lamivudine therapy and enhances viral replication in vitro. J Virol (2003) 77(21):11833-41. doi:10.1128/JVI.77.21.11833-11841.2003

145. Mokaya J, McNaughton AL, Hadley M, Beloukas A, Geretti A-M, Goedhals D, et al. A systematic review of hepatitis B virus (HBV) drug and vaccine escape mutations in Africa: a call for urgent action. bioRxiv (2018). doi:10.1101/258350

146. Oniangue-Ndza C, Kuntzen T, Kemper M, Berical A, Wang YE, NeumannHaefelin C, et al. Compensatory mutations restore the replication defects caused by cytotoxic $\mathrm{T}$ lymphocyte escape mutations in hepatitis $\mathrm{C}$ virus polymerase. J Virol (2011) 85(22):11883-90. doi:10.1128/JVI.00779-11

147. Peyerl FW, Bazick HS, Newberg MH, Barouch DH, Sodroski J, Letvin NL. Fitness costs limit viral escape from cytotoxic $\mathrm{T}$ lymphocytes at a structurally constrained epitope. J Virol (2004) 78(24):13901-10. doi:10.1128/JVI.78. 24.13901-13910.2004

148. Brockman MA, Schneidewind A, Lahaie M, Schmidt A, Miura T, DeSouza I, et al. Escape and compensation from early HLA-B57-mediated cytotoxic T-lymphocyte pressure on human immunodeficiency virus type 1 gag alter capsid interactions with cyclophilin A. J Virol (2007) 81(22):12608-18. doi:10.1128/JVI.01369-07

149. Hoofnagle JH. Reactivation of hepatitis B. Hepatology (2009) 49(5 Suppl): S156-65. doi:10.1002/hep.22945

150. Loomba R, Liang TJ. Hepatitis B reactivation associated with immune suppressive and biological modifier therapies: current concepts, management strategies, and future directions. Gastroenterology (2017) 152(6): 1297-309. doi:10.1053/j.gastro.2017.02.009

151. Sugauchi F, Tanaka Y, Kusumoto S, Matsuura K, Sugiyama M, Kurbanov F, et al. Virological and clinical characteristics on reactivation of occult hepatitis B in patients with hematological malignancy. J Med Virol (2011) 83(3):412-8. doi:10.1002/jmv.21995

152. Kempinska A, Kwak EJ, Angel JB. Reactivation of hepatitis B infection following allogeneic bone marrow transplantation in a hepatitis B-immune patient: case report and review of the literature. Clin Infect Dis (2005) 41(9):1277-82. doi:10.1086/496924

153. Mok MY, Ng WL, Yuen MF, Wong RW, Lau CS. Safety of disease modifying anti-rheumatic agents in rheumatoid arthritis patients with chronic viral hepatitis. Clin Exp Rheumatol (2000) 18(3):363-8.

154. Ito S, Nakazono K, Murasawa A, Mita Y, Hata K, Saito N, et al. Development of fulminant hepatitis B (precore variant mutant type) after the discontinuation of low-dose methotrexate therapy in a rheumatoid arthritis patient. Arthritis Rheum (2001) 44(2):339-42. doi:10.1002/1529-0131 (200102) 44:2<339::AID-ANR51>3.0.CO;2-Q

155. Esteve M, Saro C, Gonzalez-Huix F, Suarez F, Forne M, Viver JM. Chronic hepatitis B reactivation following infliximab therapy in Crohn's disease patients: need for primary prophylaxis. Gut (2004) 53(9):1363-5. doi:10.1136/ gut.2004.040675

156. Kajiwara E, Tanaka Y, Ohashi T, Uchimura K, Sadoshima S, Kinjo M, et al. Hepatitis B caused by a hepatitis B surface antigen escape mutant. J Gastroenterol (2008) 43(3):243-7. doi:10.1007/s00535-007-2150-9

157. World Health Organization. Global Hepatitis Report 2017. Geneva: World Health Organization (2017).

158. Bertoletti A, Bert NL. Immunotherapy for chronic hepatitis B virus infection. Gut Liver (2018). doi:10.5009/gnl17233

159. Bertoletti A, Tan AT, Koh S. T-cell therapy for chronic viral hepatitis. Cytotherapy (2017) 19(11):1317-24. doi:10.1016/j.jcyt.2017.07.011

160. Wisskirchen K, Metzger K, Schreiber S, Asen T, Weigand L, Dargel C, et al. Isolation and functional characterization of hepatitis B virus-specific T-cell receptors as new tools for experimental and clinical use. PLoS One (2017) 12(8):e0182936. doi:10.1371/journal.pone.0182936

161. Rehermann B, Ferrari C, Pasquinelli C, Chisari FV. The hepatitis B virus persists for decades after patients' recovery from acute viral hepatitis despite active maintenance of a cytotoxic T-lymphocyte response. Nat Med (1996) 2(10):1104-8. doi:10.1038/nm1096-1104

162. Kaymakoglu S, Baran B, Onel D, Badur S, Atamer T, Akyuz F. Acute hepatitis $B$ due to immune-escape mutations in a naturally immune patient. Acta Gastroenterol Belg (2014) 77(2):262-5.

163. Ye Q, Shang S-Q, Li W. A new vaccine escape mutant of hepatitis B virus causes occult infection. Hum Vaccin Immunother (2015) 11(2):407-10. doi:1 $0.4161 / 21645515.2014 .994461$

164. Mendy M, D’Mello F, Kanellos T, Oliver S, Whittle H, Howard CR. Envelope protein variability among HBV-Infected asymptomatic carriers and immunized children with breakthrough infections. J Med Virol (2008) 80(9):1537-46. doi:10.1002/jmv.21221

165. Zhang M, Ge G, Yang Y, Cai X, Fu Q, Cai J, et al. Decreased antigenicity profiles of immune-escaped and drug-resistant hepatitis B surface antigen (HBsAg) double mutants. Virol J (2013) 10:292. doi:10.1186/1743$422 \mathrm{X}-10-292$ 
166. Lacombe K, Boyd A, Gozlan J, Lavocat F, Girard P-M, Zoulim F. Drugresistant and immune-escape HBV mutants in HIV-infected hosts. Antivir Ther (2010) 15(3 Pt B):493-7. doi:10.3851/IMP1495

167. Sloan RD, Ijaz S, Moore PL, Harrison TJ, Teo CG, Tedder RS. Antiviral resistance mutations potentiate hepatitis B virus immune evasion through disruption of its surface antigen a determinant. Antivir Ther (2008) 13(3):439-47.

168. Baxa DM, Thekdi AD, Golembieski A, Krishnan PV, Sharif O, Kizy A, et al. Evaluation of anti-HBV drug resistant mutations among patients with acute symptomatic hepatitis B in the United States. J Hepatol (2013) 58(2):212-6. doi:10.1016/j.jhep.2012.09.014

169. Coppola N, Tonziello G, Colombatto P, Pisaturo M, Messina V, Moriconi F, et al. Lamivudine-resistant HBV strain rtM204V/I in acute hepatitis B. J Infect (2013) 67(4):322-8. doi:10.1016/j.jinf.2013.06.006
Conflict of Interest Statement: The authors declare that the research was conducted in the absence of any commercial or financial relationships that could be construed as a potential conflict of interest.

The handling Editor declared a past co-authorship with one of the authors PK.

Copyright (C) 2018 Lumley, McNaughton, Klenerman, Lythgoe and Matthews. This is an open-access article distributed under the terms of the Creative Commons Attribution License (CC BY). The use, distribution or reproduction in other forums is permitted, provided the original author(s) and the copyright owner(s) are credited and that the original publication in this journal is cited, in accordance with accepted academic practice. No use, distribution or reproduction is permitted which does not comply with these terms. 